\title{
Chapter 3 \\ Territorial and Digital Borders \\ and Migrant Vulnerability Under \\ a Pandemic Crisis
}

\author{
Petra Molnar
}

\subsection{Introduction: The Harmful Ecosystem of Migration Management Technologies}

We are Black and the border guards hate us. Their computers hate us too. - Adissu, living without immigration status in Brussels, Belgium ${ }^{1}$

Tucked away on a quiet street minutes from a major train station in Brussels, a house is at first indistinguishable from its nondescript neighbours. However, inside this 'squat' lives a bustling community. Made up of climate justice organisers, selfdescribed anarchists, and social justice advocates, L'Autre Caserne provides shelter, food, and support to undocumented people who find themselves living in the Belgian capital. With a massive cardboard clock that reads 'Revolution Time' and 'No One is Illegal' stickers everywhere, the bright three-story building has skylight windows and even a salsa dance room, contrasting with the ever-present threat of eviction and arrest. On a sunny Sunday afternoon, over 30 undocumented people gathered together to share snacks and stories of their migration journeys, while sheltering in place during the Covid-19 pandemic. ${ }^{2}$ Most people present were from Eritrea or

\footnotetext{
${ }^{1}$ Interviews collected in spring and summer of 2020. All names and identifying features have been changed to protect the people who generously shared their stories with us as they appear in Molnar (2020). For additional discussion of methodology, see also Benvenisti (2018).

${ }^{2}$ These interviews form a part of a year-long study since October 2019 to interrogate the effects of migration management technologies on the lives and rights of people on the move and to foreground the lived experiences of these communities. However, the pandemic shifted the mode of engagement due to the difficulty of safely conducting on-the-ground research and interviews with affected groups. As such, in addition to in-person research which only became possible in the summer of 2020, this report provides initial analysis and reflections on the need to employ a human rights-oriented harm-focused approach to the development, deployment, and regulation of migra-
}

P. Molnar $(\bowtie)$

Refugee Law Lab, York University, Toronto, Canada

e-mail: pmolnar@yorku.ca

A. Triandafyllidou (ed.), Migration and Pandemics, IMISCOE Research Series,

https://doi.org/10.1007/978-3-030-81210-2_3 
Ethiopia, as the previous group of Syrians vacated their rooms a few weeks back, moving on and trying their luck with the elusive passage to the UK - a Promised Land that seems simultaneously full of opportunity yet unattainable except for a lucky few. The UK remains difficult to reach during the coronavirus pandemic, where irregular passage on a boat across the English Channel or on the back of a lorry all come with the risk of increased surveillance (Meaker, 2020) and potential indefinite detention, if apprehended.

Since the coronavirus lockdown started, this community in central Brussels has been sheltering in place together for nearly three months but many said they were itching to try their luck elsewhere, no matter the cost.

'I am tired', says Negasi, a young man in his twenties from Ethiopia. 'I am tired and I want to go to the UK'. Negasi has been in Belgium for two years without papers and in Nuremberg, Germany, for five years before that. But this is not Negasi's first time in Belgium: he was deported to Germany once before, after being apprehended by the Belgian police for sleeping in a park when he was homeless. His fingerprints set off a notification in the EURODAC system (the (European Asylum Dactyloscopy Database which records and matches people's fingerprints across the EU) since he had previously filed for asylum in Germany. He said the biometric collection process was invasive, but he did not know what do to: 'How can I say no when the police handcuffed me, brought me to the station, and forced me to give them my fingerprints?' He knows of a few friends who even went as far as to burn their fingerprints off to avoid detection but Negasi thinks 'this don't solve the problem', as lack of identification usually will mean longer detention. As a young Black man, Negasi remembers his interactions with the Belgian police vividly during his 30 days in jail before being deported to Germany. 'They hit and kicked me and said "if you're not happy with this life, go back to your fucking country." They really have no respect for us, not today and not ever'.

Negasi, like many others in the community has had a complicated journey to Belgium. When he left Ethiopia, he made his way to Sudan, Chad, and Libya, before taking a boat across the Mediterranean in 2014. His journey echoes a similar path that brought Amari to Brussels. In his forties and serving as the community's Amharic interpreter, Amari doesn't remember how long he has been in Belgium exactly; he entered Europe through Italy and tried to join his sister in Sweden but was returned and made his way to Belgium.

According to Amari, the general feeling is that 'people think they have better chances if they go upwards', into western and northern Europe. Many try to forget the horrors they experienced on their way. Amari was jailed for a year and a half in

tion management technologies and forms the starting point of a broader multi-year project on these issues. The resulting report, 'Technological Testing Grounds: Migration Management Experiments from the Ground Up' (Molnar 2020), reflects interviews with over 40 refugees, asylum seekers, migrants without status, and people on the move that were conducted in Brussels, Belgium, and various locations in Greece over the summer and early fall of 2020. Additionally, 35 meetings and interviews with civil society organisations, government and private sector representatives, and academics were conducted, alongside extensive desk research. 
an underground Libyan bunker because he did not have enough money to pay the smugglers to take him across the Mediterranean (Mannocchi, 2019). He eventually escaped and joined a friend who was able to secure them both a passage to Italy. His face changed immediately when recalling his time in Libya and it was clear that the scars of that time remain: 'It's incredibly difficult to live in this world right now'. To cope, he is helping the 'squat' organisers make a 3D model of the detention facility from memory, both to document what happened to him and to perhaps help with his asylum claim, if he ever has a chance to file one. For now, Amari remains stuck in Belgium but has his eye on the UK or 'whatever country takes me'. He was planning to try and catch a lorry to the UK sometime during the following week, aware of the risks but unwilling to remain in stasis any longer because of the coronavirus. Amari has experienced torture in a Libyan jail yet says 'living without papers in a racist country is another torture. I only need papers to live. I want to study now. I want to have a reason to live'.

At multiple points in their journey that landed them in Brussels, this community interacted with surveillance technology and biometrics. Kaleb, a married man in his thirties who 'misses [his] beloved wife Liya everyday' reflected on how violent and impersonal the immigration and asylum system is. Twirling his wedding ring during the entire time we spoke, Kaleb reflected on feeling 'like a piece of meat without a life, just fingerprints and eye scans'. As Kaleb spoke, the others in the circle nodded: 'It is the human touch that keeps us warm - now all around us it's cold as fuck'. Kaleb has not seen his wife in four years.

The group was disturbed by the coldness and dehumanisation of technology. As Eshe, a young woman who did not stay long at our meeting put it, "their computers are making decisions for us'. The use of drones in the Mediterranean and the English Channel prompted many people to shake their heads, with Amari making others laugh: 'now we have flying shit instead of more help'. When discussing the use of tools like AI lie detectors at the border or drones patrolling the Mediterranean, the group discussion got heated: 'We are Black and the police [border guards] hate us. Their computers hate us too'. The threat of police presence and increased surveillance is ever-present in an occupied building full of undocumented people - in fact, the police have been coming to the squat repeatedly over the last few weeks as the coronavirus lockdowns eased, once to investigate a death from an overdose of a young Moroccan man without papers and a few other times because the neighbours made a noise complaint.

Many in the community were not aware of what exact technologies they may have come in contact with over the course of the many months - and in some cases years - of travel. But Kaleb reflected on how he found it 'weird' that new tools were being used to control migration when instead 'the world government should work on the main problem, like fighting and wars' - problems that force people to seek a better life in the first place. ${ }^{3}$

\footnotetext{
${ }^{3}$ Sadly, at the time of writing in the fall of 2020, L'Autre Caserne community has been evicted and the entire community displaced.
} 


\subsection{Real World Impacts of Technological Experiments in Pandemic Times}

Adissu, Kaleb, and Eshe's stories highlight the far-reaching individual impacts of migration surveillance technologies, exacerbated in the securitised and biosurveilled world of Covid-19. Their reflections show just how little engagement there has been with the experiences of communities at the sharp edges of these unregulated technological developments. Each individual perspective is also firmly situated in broader ecosystems of migration management and border surveillance technologies, encouraging zones of experimentation with little oversight and accountability.

People on the move like Adissu are stuck in an ever-growing panopticon of technological experiments increasingly making their way into migration management. A whole host of actors and players operate in the development and deployment of migration control technologies, obscuring responsibility and liability, exacerbating racism and discrimination, and obfuscating meaningful mechanisms of redress. Communities made under-resourced and marginalised such as non-citizens, refugees, and people on the move often have access to less robust human rights protections and fewer resources with which to defend those rights and thus become technological testing grounds.

Now, as governments move toward increasing biosurveillance (Cliffe, 2020) to contain Covid-19's spread, we are seeing a growth in tracking projects and automated surveillance technology, justified by the need to control the virus (Lewis \& Mok, 2020). However, if previous use of technology is any indication, refugees and people crossing borders will be disproportionately targeted and negatively affected. Various proposed tools sound quite far-fetched, such as virus-targeting robots (The Current, 2020), cellphone tracking (Romm, 2020), and AI-based thermal cameras (Cox, 2020). However, given the robust migration management technology ecosystem that already exists, these Covid-specific tools can all easily be used against people crossing borders, with far-reaching human rights impacts. This use of technology to manage and control migration is also shielded from scrutiny because of its emergency nature. The basic protections that exist for more politically powerful groups that have access to mechanisms of redress and oversight are often not available to people crossing borders. The current global digital rights space also does not sufficiently engage with migration issues, at best only tokenising the involvement from both migrants and groups working with this community.

Ultimately, the primary purpose of the technologies used in migration management is to track, identify, and control those crossing borders. The issues around emerging technologies in the management of migration are not just about the inherent use of technology but rather about how it is used and by whom, with states and private actors setting the stage for what is possible and which priorities matter. The data-gathering inherent in the development of these technologies also includes the expansion of existing mass-scale databases underpinning these practices to sensitive data, especially biometrics. Such data and technology systems provide an 
enabling infrastructure for many automated decision-making projects with potentially harmful implications. The development and deployment of migration management is ultimately about decision-making by powerful actors on communities with few resources and mechanisms of redress.

The introduction of new technologies impacts both the processes and outcomes associated with decisions that would otherwise be made by administrative tribunals, immigration officers, border agents, legal analysts, and other officials responsible for the administration of immigration and refugee systems, border enforcement, and refugee response management. Border enforcement and immigration and refugee decision-making sit at an uncomfortable legal nexus: the impact on the rights and interests of individuals is often very significant, even where the degree of deference is high and the procedural safeguards are weak. There is also a serious lack of clarity surrounding how courts will interpret administrative law principles like natural justice, procedural fairness, and standard of review where an automated decision system is concerned or where an opaque use of technology operates. As such, it is concerning that we are already seeing a rise in Covid-specific technologies aimed at strengthening border security, aiding in data gathering, and automatic discretionary processes and decision-making with little oversight and accountability.

The political economy in which this technological development and deployment occurs also cannot be ignored. The unequal distribution of benefits from technological development privileges the private sector as the primary actor in charge of development, with states and governments wishing to control the flows of migrant populations benefiting from these technological experiments. Governments and large organisations are the primary agents who benefit from data collection (Okediji, 2018) and affected groups remain the subject, relegated to the margins. It is therefore not surprising that the regulatory and legal space around the use of these technologies remains murky and underdeveloped, full of discretionary decision-making, privatised development, and uncertain legal ramifications.

This chapter draws on data collected during a year-long study with European Digital Rights (EDRi) to interrogate the effects of migration management technologies on the lives and rights of people on the move and to foreground the lived experiences of these communities (see Molnar, 2020). This chapter reflects some of the interviews with over 40 refugees, asylum seekers, migrants without status, and people on the move conducted in Brussels, Belgium, and various locations in Greece over the summer and early fall of $2020 .{ }^{4}$ The first section canvases some of the human rights ramifications of migration- and Covid-tech, followed by an analysis of some of the private sector drivers behind this turn to biosurveillance and migration management technologies, arguing that this pandemic emergency provides the perfect foil to fast-track problematic surveillance and automated digital technologies

\footnotetext{
${ }^{4}$ All interviews adhered to strict Covid-19 social distancing protocols and negative testing as necessary before entering Lesvos and other areas in Greece; 35 meetings and interviews with civil society organisations, government and private sector representatives, and academics were also conducted, alongside extensive desk research.
} 
without taking into account their impacts on the rights and lives of people on the move.

\subsection{Human Rights Ramifications of Migration- and Covid-Tech}

Like a piece of meat without a life, just fingerprints and eye scans. - Kaleb, living without immigration status in Brussels, Belgium

Technologies such as automated decision-making, biometrics, and unpiloted drones are increasingly controlling migration and affecting millions of people on the move. This allure of using technological interventions at and around the border highlights the very real impacts on people's rights and lives, exacerbated by a lack of meaningful governance and oversight mechanisms of these technological experiments.

Even before the pandemic, surveillance and automated decision-making technologies had been increasingly used in securing border spaces, infringing on people's life and liberty and their freedom of movement. For example, Frontex, the European Border and Coast Guard Agency, announced an expanded border strategy bolstered by a new regulation (Frontex, 2019) which relies on increased staff and new technology. An EU-funded project, ROBORDER (n.d.), explicitly 'aims to create a fully functional autonomous border surveillance system with unmanned mobile robots including aerial, water surface, underwater and ground vehicles'. The EU borders are not the only site of drone technology. In the US, politicians have presented similar 'smart-border' technologies as a more 'humane' alternative to the Trump Administration's calls for a physical wall. Most recently, this includes a partnership between the US Customs and Border Protection, Google Cloud AI, and Anduril Industries to create a new 'virtual' wall of surveillance towers and drones, a move that has been endorsed by the Biden Administration (Fang \& Biddle, 2020; also Bernd, 2021). However, these technologies can have drastic results. For example, border control policies that use new surveillance technologies along the US-Mexico border have actually doubled migrant deaths (Boyce et al., 2019) and pushed migration routes towards more dangerous terrain through the Arizona desert, creating what anthropologist Jason De Leon calls a 'land of open graves' (De Leon \& Wells, 2015). With similar surveillance technology increasingly used on the shores of Europe to facilitate interceptions and pushbacks of boats (Forensic Architecture, 2020; Heller \& Jones, 2014; Keady-Tabbal \& Mann, 2020), a similar increase of watery graves will likely occur (see Border Violence Monitoring Network, n.d.). Given that the International Organization for Migration (IOM) has reported that due to recent shipwrecks, over 20,000 people have died trying to cross the Mediterranean since 2014 (Black, 2020), we can only imagine how many more bodies will wash upon the shores of Europe as the situation worsens along the EU's borders. The use of these technologies by border enforcement is only likely to 
increase in the 'militarised technological regime' (Csernatoni, 2018) of border spaces, without appropriate public consultation, accountability frameworks, and oversight mechanisms. This increased reliance on border securitisation and surveillance through new technologies, as clearly underscored by the EU's New Migration Pact (European Commission, 2020) and its focus on border enforcement and deterrence, also works to send a clear message that human lives are expendable to protect Europe's borders.

We should not underestimate the far-reaching impacts of new technologies on the lives and rights of people on the move. The right to life and the right liberty, the right to be free from discrimination, the right to privacy, and a host of other fundamental internationally protected rights are highly relevant to technological experimentation in migration and refugee contexts. ${ }^{5}$ For example, aspects of training data which are mere coincidences in reality may be treated as relevant patterns by a machine-learning system, leading to arbitrary, incorrect, or discriminatory outcomes. ${ }^{6}$ Given the problematic track record that automated technologies already have on race and gender, similar issues likely occur in migration surveillance and decision-making. Proxies for discrimination, such as country of origin, can be used to make problematic inferences leading to discriminatory outcomes.

Algorithms are vulnerable to the same decision-making concerns that plague human decision-makers: transparency, accountability, discrimination, bias, and error (Tufekci, 2015). The opaque nature of immigration and refugee decisionmaking creates an environment ripe for algorithmic discrimination. Decisions in this system - from whether a refugee's life story is 'truthful' to whether a prospective immigrant's marriage is 'genuine' - are highly discretionary, and often hinge on assessment of a person's credibility (Satzewich, 2015). To the extent that these technologies will be used to assess 'red flags', 'risk' and 'fraud', they also raise definitional issues, as it remains unclear what the parameters of these markers will be.

These risks are not merely speculative. Biases at the border have far-reaching results if they are embedded in the emerging technologies being used experimentally in migration. For example, in airports in Hungary, Latvia, and Greece, a new pilot project by a consortium called iBorderCtrl introduced AI-powered lie detectors at border checkpoints (Picheta, 2018). ${ }^{7}$ The project claimed that passengers' faces would be monitored for signs of lying, and if the system became more 'sceptical' through a series of increasingly complicated questions, the person would be selected for further screening by a human officer. Canada and Romania have also

\footnotetext{
${ }^{5}$ For a fulsome analysis of the applicability of international human rights law and the variety of rights engaged in migration management technologies, see Petra Molnar (2019).

${ }^{6}$ This is one reason why the EU's General Data Protection Regulation (GDPR) requires the ability to demonstrate that the correlations applied in algorithmic decision-making are 'legitimate justifications for the automated decisions. See for example Lokke Moerel and Marijn Storm (2018).

${ }^{7}$ With Hungary and Greece being some of the crucial entry points for refugee claimants into mainland Europe, it is perhaps no accident that these locations were chosen as the site of experimentation.
} 
experimented with a similar border-screening 'emotion-recognition' project called AVATAR (Daniels, 2018; Kendrick, 2019). ${ }^{8}$

However, it is unclear how these systems will be able to handle cultural differences in communication or account for trauma and its effects on memory, such as when dealing with a traumatised refugee claimant unable to answer questions clearly. ${ }^{9}$ Refugee claims and immigration applications are filled with nuance and complexity, qualities that may be lost on automated technologies, leading to serious breaches of internationally and domestically protected human rights in the form of bias, discrimination, privacy breaches, and due process and procedural fairness issues, among others. It remains unclear how the right to a fair and impartial decision-maker and the right to appeal a decision will be upheld during the use of automated decision-making systems. ${ }^{10}$

The complexity of human migration is not easily reducible to an algorithm. Yet states are willing to experiment with these new unregulated technologies in the space of migration precisely because it is a discretionary space of opaque decisionmaking. The development and deployment of technologies also reinforce the NorthSouth power asymmetries and concretise which locations are seen as innovation centres, while spaces like conflict zones and refugee camps become sites of experimentation under the guise of 'humanitarianism' and 'empowerment of migrants' through innovation. ${ }^{11}$ Technological innovations exude the promises of increased fairness and efficiency. Moreover, much of migration management is also enacted by international organisations such as the UNHCR and IOM. As non-state actors operating under various legal and quasi-legal authorities and regulations globally, international organisations are 'arenas for acting out power relationships' (Evans \& Wilson, 1992) without being beholden to the responsibilities that states have to protect human rights. States that operate through international organisations can also 'launder' their legal responsibility for acts or omissions that are attributed to the organisation (Benvenisti, 2018). With the proliferation of migration control technologies, international organisations are overly empowered to administer technology without having to abide by rights-protecting laws and principles, resulting in problems with compliance (See, for example, Raustiala \& Slaughter, 2002).

\footnotetext{
${ }^{8}$ Various other pilot projects to introduce facial recognition at the border across the world have been explored in a recent report by CIPPIC (see Israel 2020).

${ }^{9}$ These issues also of course exist with human decision-makers, and there are increasingly cogent critiques about officers misunderstanding how the psychological effects of repeated trauma can impacts person's ability to testify and appear 'truthful.' See for example the work of Hilary Evans Cameron, Refugee Law's Fact-Finding Crisis: Truth, Risk, and the Wrong Mistake (Cambridge University Press, Cambridge 2018).

${ }^{10}$ There has been much opposition to the iBorderCTRL project, with a number of civil society organisations speaking out. For example, in November 2018, Homo Digitalis filed a petition to the Greek Parliament regarding the pilot implementation of the iBorderCtrl project (see Chelioudakis 2018).

${ }^{11} \mathrm{See}$, for example, initiatives such as 'Techfugees: Empowering the Displaced Through Technology' https://techfugees.com/, accessed 17 March 2019.
} 
The appetite for these advances also reveals the fissures of imbalanced power relations in society. Technological development does not occur in a vacuum but replicates existing power hierarchies and differentials. Technology is not inherently democratic, and issues of informed consent and right of refusal are particularly salient in humanitarian and forced migration contexts when, for example, refugees in Jordan have their irises scanned in order to receive their weekly rations under the justification of efficiency, while not being able to refuse biometric registration (Staton, 2016). Technologies of migration management also operate in an inherently global context. They reinforce institutions, cultures, policies, and laws, and exacerbate the gap between the public and the private sector, where the power to design and deploy innovation comes at the expense of oversight and accountability.

Unfortunately, an exceptional crisis moment like a global pandemic seems to be accelerating the development of technological interventions in and around the border without appropriate safeguards and oversights. This push to render people on the move as viable testing communities for further surveillance opens up spaces for greater justifications for border enforcement and securitisation, particularly in frontier zones with little oversight and accountability, rife for the private sector to foreground profit-making as the priority agenda.

\subsection{Politics, Pandemics, and Privatisation of Migratory Spaces}

Their computers are making decisions for us. - Eshe, living without status in Brussels, Belgium

Pandemic responses are political (Khatin, 2020; also, Arundhati, 2020). Refugees have long been tied to tropes of bringing disease and illness (The World, 2019), underscored by growing xenophobia and racism (UNHCR, 2020). Not only are these formulations inaccurate; they also legitimise incursions on human rights (Herrera, 2019). If previous use of technology is any indication, refugees and people crossing borders will be disproportionately targeted and Covid-tracking technology can be easily co-opted to impact communities made marginalised (Lukacs, 2020). Making people on the move more trackable and detectable justifies the use of more technology and data collection in the name of public health and national security.

Most importantly, technological solutions do not address the root causes of displacement, forced migration, and economic inequality, all of which exacerbate the spread of global pandemics like Covid-19 (Molnar \& Naranjo, 2020). Coupled with extraordinary state powers, the incursion of the private sector's solutions presented to manage both migration and the pandemic leaves open the possibility of grave human rights abuses and far-reaching effects on civil liberties, particularly for communities on the margins. 


\subsection{Pandemics at the Frontier: Greek Refugee Camps in the Age of Surveillance}

Certain places serve as the perfect testing grounds for new technologies, places where regulation is limited and where an 'anything goes' frontier attitude informs the development and deployment of surveillance at the expense of humanity. Greece is one of these places, a surveillance sandbox at the frontiers of Europe.

Moria, Europe's largest refugee camp, burned to the ground on 9 September 2020. I visited Lesvos in the aftermath to document the building on a new containment centre and begin mapping out how this locale fits into broader narratives of technological experimentation. After the fire, thousands of people were sequestered on a barren stretch of road (Lavella, 2020) without food or water, tear-gassed (BBC News, 2020), and then herded into a new camp hastily built on the grounds of an old shooting range on a windswept peninsula (Solomon, 2020). This rocky outcropping is the newest site of containment on Europe's borders, one housing over 9000 people displaced during a global pandemic, with no idea when or how they will be able to leave.

However, instead of opening the island camps and coming up with a meaningful plan for years of inaction, the EU's new Migration Pact explicitly doubles down on containment and border security, opening the door to increasingly draconian tools of surveillance using new technologies - including the use of facial recognition not just on adults but also on minors (European Commission, 2020). More and more, violent uses of technology work to push European borders farther afield (Howden et al., 2019), contributing to policies of border externalisation (Hernàndez, 2020), making Europe's migration issues someone else's problem. These policies have direct and dire consequences - drownings in the Mediterranean (Trilling, 2020), pushbacks to Libya (Kingsley, 2020) and Turkey, including using floating tents (Keady-Tabbal \& Mann, 2020), and years-long detention in decrepit camps like Moria and other sites on islands like Samos, Chios, and Kos.

Frontier countries like Greece, 'Europe's Shield' (Jamieson et al., 2020), act as testing grounds for new technologies and surveillance mechanisms. In October 2019, new legal rules were adopted as regards the deployment of drones by the Hellenic Police (Presidential Decree 98/2019), including the use of drones to monitor migration in border regions. Groups like Homo Digitalis in Greece claim that the new rules do not address the challenges arising from the applicable data protection legislation and have filed an open letter to the Ministry of Citizen Protection requesting more information about the deployment of drones by the Hellenic Police (Homo Digitalis, 2020). Drones, along with cameras and various other surveillance technologies are also being used and tested along the Evros land border with Turkey, in an increasing push to militarise migration management (Human Rights 360, 2020; also, Kalafatis, 2020; also Gatopoulos \& Kantouris, 2021).

In September 2020, Frontex also announced that it was piloting a new aerostat maritime surveillance system (Frontex, 2020b), using Greece as a testing ground. The current pandemic conditions must also not be discounted, as they will likely 
expedite and exacerbate the turn to technological solutions at the border. We are already seeing the border industry pushing for increased adoption of 'contactless biometrics' for 'regular' travellers as a way of stopping contagion (PR Newswire, 2020). Frontex in particular has been clear in its messaging to position itself as an agency apt at both controlling migration as well as the spread of Covid-19. According to a May 2020 press release, "if we cannot control the external borders, we cannot control the spread of pandemics in Europe. Frontex plays a key role in ensuring effective protection of the external borders of the European Union not only against cross-border crime but also against health threats' (Frontex, 2020a). The EU continues to make its priorities clear: containment, surveillance, and technosolutionism at the expense of human rights (Molnar, 2021).

The appetite for migration management technologies remains present in Greece, with the Hellenic Ministry of Migration and Asylum co-hosting and supporting the World Border Security Congress in the fall of 2021, a gathering of public and private actors eager to address 'threats' such as 'ISIS threatens to send 500,000 migrants to Europe' and 'Migrants and refugees streaming into Europe from Africa, the Middle East, and South Asia'. ${ }^{12}$ And as recently as December 2020, tech giant Palantir proudly announced a partnership with the Greek government, stating: 'Our partnership with the Greek government was borne out of necessity once the pandemic began, and we look forward to broadening it for years to come' (Business Wire, 2020). It is currently unclear what exactly this partnership entails but it bears to remember that Palantir is the same company that has been facilitating ICE detentions and deportations at the US-Mexico border (Frenkel, 2018) and has been implicated in a host of other human rights abuses (Hemmadi, 2019; O'Brien, 2020).

The use of technology is never neutral - it reinscribes the way that powerful actors make decisions that affect thousands of people. Along with Big Tech, big money is also involved in the management of borders, with private security companies making major inroads (Privacy International, n.d.) with lucrative contracts procured by governments for shiny new tech experiments presented as a way to strengthen border security. These technological experiments also play up the 'us' vs 'them' mentality at the centre of migration management policy. Instead of longterm viable redistribution of resources across the EU and timely processing of people's asylum, turning to techno-solutionism (Molnar \& Naranjo, 2020) and migration surveillance will only exacerbate deterrence mechanisms already so deeply embedded in the EU's migration strategy.

Various people in our interviews on Lesvos were concerned about proposed screening and surveillance mechanisms to keep people contained, tracked, and managed and the normalisation of surveillance in the aftermath of the Moria fire. Yet no one was clear on exactly how the next few months would shape up, particularly regarding increasingly technological incursions, data collection, and surveillance. However, the planned rollout in 2021 of so-called Multi-Purpose Reception and Identification Centres (MPRICs) on the islands of Lesvos, Samos, Leros, Chios,

\footnotetext{
${ }^{12}$ See provisional programme at https://world-border-congress.com/
} 
and Kos all seem to indicate a turn to both containment and surveillance, creating what are essentially closed prison camps complemented by 'camera surveillance with motion analysis algorithms monitoring the behaviour and movement of centre residents' (Europe Must Act, 2021; Petridi, 2021). Clearly, migration management through technology is firmly on the agenda.

Given the far-reaching and high-risk nature of these technological experiments, the unique context of migration should be the central consideration when analysing which human rights should be taken into consideration when exploring new technologies, given the very real risks to life, liberty, and security, as well as heightened privacy considerations, particularly during an unprecedented global pandemic. Yet states can justify technological experiments in migration control precisely because migrants are not able to exercise the same rights as citizens and because they are seen as a useful tool through which to exercise powers of sovereignty in an increasingly destabilised world.

\subsection{Big Tech and Big Profit in the Privatisation of Migration Management}

Ultimately, the primary purpose of the technologies used in migration management is to track, identify, and control those crossing borders - and now doing so in the middle of a global health crisis. The issues around emerging technologies in the management of migration are not just about the inherent use of technology but rather about how it is used and by whom, with states and private actors setting the stage for what is possible and which priorities matter. The data-gathering inherent in the development of these technologies also includes the expansion of existing mass-scale databases that underpin these practices to sensitive data, especially biometrics. Such data and technology systems provide an enabling infrastructure for many automated decision-making projects with potentially harmful implications. The development and deployment of migration surveillance technologies is ultimately about decision-making by powerful actors on communities with few resources and mechanisms of redress, which becomes justified by the state of emergency such as a global pandemic.

Politics also cannot be discounted, as migration management is inherently a political exercise. Migration data is already being politicised to support greater interventions in defence of threatened national sovereignty (Scheel \& Ustek-Spilda, 2018), reinforcing politics of exclusion. The state's ultimate power to decide who may enter and under what conditions (ibid.) is bolstered by ongoing beliefs in technological impartiality. However, there is an inherent tension between the claimed prerogative of nation-states over sovereignty and the malleable nature of technology. In its fluidity, technology is inherently oppositional to borders, and by extension sovereignty. Indeed, oftentimes it impinges on the very definition of 'humanness' in the digital era (Zureik \& Hindle, 2004). Ultimately, the primary purpose of the 
technologies used in migration management is to track, identify, and control those crossing borders. The unequal distribution of benefits that accrue in technological development work to create monopolies of knowledge and consolidate power and authority vested in the sovereign state. These monopolies exist because there is no unified global regulatory regime governing the use of new technologies, creating laboratories for high-risk experiments with profound impacts on people's lives.

Even before the pandemic, the human body itself increasingly became the embodiment of progressively violent and discriminatory border regimes. For example, in March 2020, the US announced that it would begin collecting DNA samples from hundreds of thousands of migrants apprehended along the US-Mexico border (Hauslohner, 2020). This practice will dramatically expand a federal database of individual genetic information used by law enforcement. ${ }^{13}$ Migrant rights groups in Mexico have also reported the use of digital technologies to spread misinformation that stigmatises migrants as criminals or carriers of diseases (Cadena, 2020), including Covid-19. The stigmatisation that coordinated digital misinformation campaigns spurred hostility towards migrants, including the risk of violence against them. There are increasing reports of harassment against migrant rights defenders and journalists covering migrant caravans in Central America, Mexico, and the US, including digital threats, searches of digital devices ${ }^{14}$ and even electronic surveillance by authorities in the US and Mexico (Jones et al., 2019).

Growing anti-migrant xenophobic sentiment, justification of surveillance and online media monitoring under the guise of security and public health, and the rise of extreme right and neo-fascist groups or political organisations globally impacts how migration management technologies function. From the Proud Boys in the US to the autocratic administration of Victor Orban in Hungary to the Maduro regime in Venezuela, people on the move and migrants have been linked to threats to national sovereignty (The World, 2019) that must be stopped at all costs - and most recently explicitly connected to the spread of the Covid-19 virus and characterised as 'vermin' and 'biological weapons' (Cohen, 2018). ${ }^{15}$. Far-right groups have been engaged in violence again migrants around the world, including in the US, mainland Europe, and Canada. In border frontiers such as Greece, far-right extremism and anti-migrant sentiments reached boiling point, with the island of Lesbos becoming an epicentre for extreme right groups across the EU (Fallon, 2020). Most recently, ties have been discovered between far-right extremists and companies like Clearview

\footnotetext{
${ }^{13}$ See Privacy International's legal submissions, https://privacyinternational.org/legal-action/ submissions.

${ }^{14} 4$ See Frontline Defenders, Red TDT, LIS-Justicia en Movimiento \& PRAMI-Universidad Iberoamericana. Defenders beyond borders: migrant rights defenders under attack in Central America, Mexico and the United States. September 2019. Available at: https://www.frontlinedefenders.org/sites/default/files/frontline_defenders_mexico_english_v2.pdf and also Privacy International submissions.

${ }^{15}$ Europe has also been exporting technology to China to aid in the repression of the Uighurs and to assist with surveillance in the Chinese concentration camps in Xingang province (see Manancourt 2020).
} 
$\mathrm{AI}$ and Palantir, which are responsible for the development and deployment of facial recognition technologies and algorithmic decision-making tools used for the detention and deportation of migrants (O'Brien, 2020). These groups have also been blatantly calling for the establishment of so-called 'deportation squads' using algorithms to identify potential targets (ibid.). The implications of Big Tech giants and corporate interests in these dangerous anti-migrant narratives is a very troubling development, all the more so because public-private partnerships lie at the heart of the development and deployment of migration management technologies.

The lack of adequate technical capacity within government and the public sector can lead to potentially inappropriate over-reliance on the private sector. Adopting emerging and experimental tools without in-house talent capable of understanding, evaluating, and managing these technologies is irresponsible and downright dangerous, as the companies and corporations hold the balance of power when determining what technology is developed and deployed, and subsequently procured by governments. Private sector actors have an independent responsibility to make sure technologies that they develop do not violate international human rights and domestic legislation. Yet much of technological development occurs in so-called black boxes, where intellectual property laws and proprietary considerations shield the public from fully understanding how the technology operates. Powerful actors can easily hide behind intellectual property legislation or various other corporate shields to launder their responsibility and create a vacuum of accountability.

These practices also give rise to the Border Industrial Complex (Miller, 2018) the confluence of border policing, militarisation, and financial interest. States are seeking to leave people on the move, refugees, and undocumented people in particular beyond the duties and responsibilities enshrined in law through an overreliance on the private sector to ensure technological experimentation occurs outside of sovereign responsibility. ${ }^{16}$ The growing role of the private sector in the governance of new technologies highlights the movement away from state responsibility to create governance structures in accordance with domestic and international principles under guise of proprietary technology, private interests, and discretion.

Increasingly, private companies are setting the migration control agenda. Whether through the automation of immigration and refugee applications, AI-powered 'lie detectors' at borders, or drone surveillance of refugee boats, the private sector is an integral player in the management of migration. States and government departments over-rely on private actors to develop and deploy technologies used to control migration. As a result, government liability and accountability are watered down and shifted to the private sector, where the legally-enforceable rights that allow individuals to challenge governments may not exist (see Statewatch,

\footnotetext{
${ }^{16}$ See for example the Canadian Government's procurement for a so-called 'Artificial Intelligence Solution,' for various immigration processes, directly calling on the private sector to be the driver of migration management technologies: Public Works and Government Services Canada, 'Artificial Intelligence Solution (B8607-180311/A),' Tender Notice (13 April 2018, amended 23 May 2018) https://buyandsell.gc.ca/procurement-data/tender-notice/PW-EE-017-33462, accessed 25 July 2019; also Molnar and Gill (2018).
} 
2020). People on the move get caught in the middle, leading to grave human rights abuses and infringements on fundamental freedoms. The opaque, private technologies deployed at border zones to control migration desperately need to be regulated. Yet, the creation of legal black holes in migration management technologies is very deliberate to allow for the creation of opaque zones of technological experimentation that would not be allowed to occur in other spaces (among others, Molnar \& Naranjo, 2020). While we are able to imagine mobilising around extreme issues such as the banning of killer robots in armed conflict, the grey spaces of migration management technology remain largely uncontested.

\subsection{Concluding Remarks: Surveillance Panacea or Safety and Health for All?}

They really have no respect for us, not today and not ever. - Negasi, living without status in Brussels, Belgium

While technology can offer the promise of novel solutions for an unprecedented global crisis, Covid-led innovation should not unfairly target refugees and people on the move, racialised communities, Indigenous communities, and other marginalised groups, or make discriminatory inferences that can lead to detention, family separation, and other irreparable harms. While often presented with a lot of promise, too often technological tools easily become tools of oppression and surveillance, denying people agency and dignity, and contributing to a global climate that is increasingly more hostile to people on the move. The pandemic is already being used to curtail access to people living in informal settlements or securitised refugee camps on Greek islands and detention centres for undocumented populations across Europe and throughout the world. However, instead of increased tracking and surveillance, a redistribution of resources, dignified living conditions, and access to medical care are paramount to stopping the spread of the pandemic.

As this chapter has highlighted, drawing on conversations with people on the move in Belgium and Greece, affected communities must be directly involved in technological development and discussions around proposed interventions, shaping and driving the conversation, not consulted as an afterthought or in a tokenising extractive way While conversations around the ethics of AI are taking place, ethics do not go far enough. What is needed is a sharper focus on oversight mechanisms grounded in fundamental human rights and context-specific accountability that recognises the particular lived experiences of people on the move and their experiences in the time of exception that is a global pandemic in an increasingly securitised and surveilled world.

Yet there is also a hopeful promise in the proliferation of new technologies in migration management. Policymakers, academia, and the public are being forced to reckon with fundamental normative ideas around what constitutes intelligence, how to manage and regulate new systems of cognition, and who should be at the table 
when designing and deploying new tools that can be used to either dismantle or reinforce the status quo. Culture, politics, institutions, and technology all iteratively shape one another. Ultimately, technology is a social construct (Franklin, 1990), a mirror to reflect the positives and negatives inherent in our societies, forcing us to rethink ideas of privilege and power in the current global crisis that is reshaping our world at every level. It remains to be seen whether the current global push towards fervent technological innovation will result in robust global governance, centred on the experiences of people on the move, or whether it will further dehumanise people on the move as they are increasingly having to contend with the sharp edges of harmful technological development in the time of a global health crisis.

\section{References}

Arundhati, R. (2020, April 3). The pandemic is a portal. Financial Times. https://www.ft.com/ content/10d8f5e8-74eb-11ea-95fe-fcd274e920ca

BBC News. (2020, September 12). Moria migrants tear-gassed by Greek police in protest over new camp. BBC. https://www.bbc.com/news/world-europe-54131212

Benvenisti, E. (2018). Upholding democracy amid the challenges of new technology: What role for the law of global governance? European Journal of International Law, 29(1), 9-82.

Bernd, C. (2021, February 2). Biden is rejecting Trump's Border Wall—But favors his own technological wall. Truthout. https://truthout.org/articles/ biden-is-rejecting-trumps-border-wall-but-proposing-his-own-virtual-wall/

Black, J. (2020, May 3). Shipwreck off coast of Libya pushes migrant Deaths on the Mediterranean past 20,000 Mark. International Organization for Migration. https://www.iom.int/news/ shipwreck-coast-libya-pushes-migrant-deaths-mediterranean-past-20000-mark

Border Violence Monitoring Network. (n.d.). https://www.borderviolence.eu/

Boyce, G. A., Chambers, S. N., \& Launis, S. (2019, February 11). Democrats' 'smart border' technology is not a 'humane' alternative to Trump's wall. The Hill. https://thehill.com/opinion/immigration/429454-democrats-smart-border-technology-is-not-a-humane-alternativeto-trumps

Business Wire. (2020). Greek Government and Palantir Reaffirm Digital Transformation Partnership. https://www.businesswire.com/news/home/20201207005526/en/

Cadena, C. Z. (2020). Peligroso foco rojo: Bomba de tiempo los migrantes asentados en Tapachula ante el coronavirus (Dangerous red spotlight: Time bomb for the migrants settled in Tapachula in the face of the coronavirus). Diario de Chiapas, 28 April 28. https://diariodechiapas.com/ opinion/peligroso-foco-rojo-bomba-de-tiempo-los-migrantesasentados-en-tapachula-ante-elcoronavirus $/ 123218$

Chelioudakis, E. (2018, November 21). Greece: Clarifications sought on human rights impacts of iBorderCtrl. EDRi. https://edri.org/our-work/ greece-clarifications-sought-on-human-rights-impacts-of-iborderctrl/

Cliffe, J. (2020, March 25). The rise of the bio-surveillance state: A grim choice faces 21stcentury societies: panopticons or pandemics? NewStatesman. https://www.newstatesman.com/ science-tech/2020/03/rise-bio-surveillance-state

Cohen, R. (2018, April 6). Opinion: How democracy became the enemy. The New York Times. https://www.nytimes.com/2018/04/06/opinion/sunday/orban-hungary-kaczynski-poland.html. https://www.nytimes.com/2018/04/06/opinion/sunday/orban-hungary-kaczynski-poland.html

Cox, J. (2020, March 17). Surveillance company says it's deploying 'CoronaDetecting' cameras in US. Vice. https://www.vice.com/en_us/article/epg8xe/ surveillance-company-deploying-coronavirus-detecting-cameras. 
Csernatoni, R. (2018). Constructing the EU's high-tech borders: Frontex and dual-use drones for border management. European Security, 27(2), 175-200.

Daniels, J. (2018, May 15). Lie-detecting computer kiosks equipped with artificial intelligence look like the future of border security. $C N B C$. https://www.cnbc.com/2018/05/15/lie-detectorswith-artificial-intelligence-are-future-of-border-security.html

De Leon, J., \& Wells, M. (2015). The land of open graves: Living and dying on the migrant trail. University of California Press.

Europe Must Act. (2021). No More Camps: Monthly Update 02/2021. https://05cd942b-77f4-4d21b3ea-797e75ad39b3.filesusr.com/ugd/0d6197_61731d4c32f245648587332a279e5033.pdf

EuropeanCommission.(2020).NewPactonMigrationandAsylum.https://ec.europa.eu/info/strategy/ priorities-2019-2024/promoting-our-european-way-life/new-pact-migration-and-asylum_en

Evans, T., \& Wilson, P. (1992). Regime theory and the English School of International relations: A comparison. Millennium: Journal of International Studies, 21(3), 329-351.

Fallon, K. (2020, May 6). How the Greek island Lesbos became a stage for Europe's far right. Al Jazeera. https://www.aljazeera.com/features/2020/5/6/ how-the-greek-island-lesbos-became-a-stage-for-europes-far-right

Fang, L. \& Biddle, S. (2020, October 21). Google AI tech will be used for Virtual Border Wall, Cbp Contract Shows. The Intercept. https://theintercept.com/2020/10/21/ google-cbp-border-contract-anduril/

Forensic Architecture. (2020). The left-to-die boat. https://forensic-architecture.org/investigation/ the-left-to-die-boat. Accessed 23 Oct 2020.

Franklin, U. (1990). The real world of technology. House of Anansi Press.

Frenkel, S. (2018, June 19). Microsoft employees protest work with ICE, as Tech Industry Mobilizes over immigration. The New York Times. https://www.nytimes.com/2018/06/19/technology/tech-companies-immigration-border.html

Frontex. (2019, April 12). New Frontex regulation comes into force. News Release. https://frontex. europa.eu/media-centre/news-release/new-frontex-regulation-comes-into-force-Soluwe

Frontex. (2020a, May 8). Europe Day - united against corona virus with eyes on the future. News release. https://frontex.europa.eu/media-centre/news-release/ europe-day-united-against-corona-virus-with-eyes-on-the-future-r9vMlS

Frontex. (2020b, September 11). Frontex to launch maritime surveillance by aerostat pilot project. News release. https://frontex.europa.eu/media-centre/news-release/ frontex-to-launch-maritime-surveillance-by-aerostat-pilot-project-KzMGfe

Gatopoulos, D. \& Kantouris, C. (2021, May 31). In post-pandemic Europe, migrants will face digital fortress. Assoated Press. https://apnews.com/article/middle-east-europe-migrationtechnology-health-c23251bec65ba45205a0851fab07e9b6. Accessed 1 June 2021.

Hauslohner, A. (2020, March 6). U.S. immigration authorities will collect DNA from detained migrants. The Washington Post. https://www.washingtonpost.com/gdprconsent/?next_url=https $\% 3 \mathrm{a} \% 2 \mathrm{f} \% 2 \mathrm{fwww}$.washingtonpost.com $\% 2$ fimmigration $\% 2$ fusimmigration-authorities-will-collect-dna-from-detained-migrants $\% 2 \mathrm{f} 2020 \% 2 \mathrm{f} 03 \% 2 \mathrm{f} 06$ \%2f63376696-5fc7-11ea-9055-5fa12981bbbf_story.html

Heller, C. \& Jones, C. (2014, February 1). Eurosur: Saving lives or reinforcing deadly borders? Statewatch. https://www.statewatch.org/statewatch-database/ eurosur-saving-lives-or-reinforcing-deadly-borders-by-charles-heller-and-chris-jones/.

Hemmadi, M. (2019, June 26). Controversial data-mining firm Palantir signs milliondollar deal with defence department. The Logic. https://thelogic.co/news/exclusive/ controversial-data-mining-firm-palantir-signs-million-dollar-deal-with-defence-department/

Hernàndez, J. (2020, September 17). Don't blame refugees for the Moria fires, blame EU policy. The New Humanitarian. https://www.thenewhumanitarian.org/opinion/2020/09/17/ Moria-camp-fires-migrants-asylum-seekers-EU.

Herrera, J. (2019, May 15). Studies Show Fears About Migration and Disease Are Unfounded. Pacific Standard. https://psmag.com/news/ studies-show-fears-about-migration-and-disease-are-unfounded 
Homo Digitalis. (2020, April 30). Open Letter to the Ministry of Citizen Protection for the use of drones by Hellenic Police. https://www.homodigitalis.gr/posts/6579

Howden, D., Fotiadis, A., \& Lowenstein, A. (2019, August 4). Once migrants on Mediterranean were saved by naval patrols. Now they have to watch as drones fly over. The Guardian. https://www.theguardian.com/world/2019/aug/04/ drones-replace-patrol-ships-mediterranean-fears-more-migrant-deaths-eu

Human Rights 360. (2020, October). Defending human rights in times of border militarisation. Monitoring Report. https://www.humanrights360.org/wp-content/uploads/2020/10/EvrosReport-19.10.pdf

Israel, T. (2020, September 30). Facial recognition at a crossroads: Transformation at our borders and beyond. Samuelson-Glushko Canadian Internet Policy \& Public Interest Clinic (CIPPIC). https://cippic.ca/uploads/FR_Transforming_Borders.pdf

Jamieson, A., Ripper, K., \& Sandford, A. (2020, March 4). Greece is 'Europe's shield' in migrant crisis, says EU chief von der Leyen on visit to Turkey border. Euronews. https://www.euronews. com/2020/03/03/greece-migrant-crisis-is-an-attack-by-turkey-on-the-eu-austria

Jones, T., Payton, M., \& Feather, B. (2019, March 6). Source: Leaked documents show the U.S. government tracking journalists and immigration advocates through a secret Database. NBC 7 Investigates (updated 10 January 2020). Available at: https://www.nbcsandiego.com/ news/local/source-leakeddocuments-show-the-us-government-tracking-journalists-andadvocates-through-a-secret-database/3438/.

Kalafatis, A. (2020, October 17). 'Frourio' me exi kiniseis o Evros: frahtis, echovolistika, tethorakismena, paratiritiria (Evros 'fortress' in 6 moves: fence, echo sounders, armoured vehicles, observatories). Ethnos. https://www.ethnos.gr/ politiki/128955_froyrio-me-6-kiniseis-o-ebros-frahtis-ihobolistika-tethorakismena-paratiritiria

Keady-Tabbal, N. \& Mann, I. (2020, May 22). Tents at Sea: How greek officials use rescue equipment for illegal deportations. Just Security. https://www.justsecurity.org/70309/ tents-at-sea-how-greek-officials-use-rescue-equipment-for-illegal-deportations/

Kendrick, M. (2019, April 17). The border guards you can't win over with a smile. BBC. https:// www.bbc.com/future/article/20190416-the-ai-border-guards-you-cant-reason-with

Khatin, L. (2020, March 31). Covid-19 impact on refugees is also political. Chatham House. https://www.chathamhouse.org/expert/comment/covid-19-impact-refugees-also-political

Kingsley, P. (2020, March 20). Privatized pushbacks: How Merchant Ships Guard Europe. The New York Times. https://www.nytimes.com/2020/03/20/world/europe/mediterranean-libyamigrants-europe.html

Lavella, M. (2020, September 11). Moria tragedy: Abandoned refugees hemmed in, given little support. Aljazeera. https://www.aljazeera.com/featuunhcrres/2020/09/11/ moria-tragedy-abandoned-refugees-hemmed-in-given-little-support/

Lewis, S., \& Mok, O. (2020, March 25). Malaysia enforces lockdown compliance with drones. Privacy International. https://privacyinternational.org/examples/3509/ malaysia-enforces-lockdown-compliance-drones

Lukacs, M. (2020, June 16). Canada's Border Agency shouldn't be using pandemic to impose surveillance on undocumented immigrants. CBC News Opinion. https://www.cbc.ca/news/ opinion/opinion-undocumented-immigrants-electronic-monitoring-1.5604467? ref=mobil erss\&cmp=newsletter_CBC\%20News\%20Top $\% 20$ Headlines $\% 20 \% 20 \%$ E2\%80\%93\%20 Morning_1174_37843

Manancourt,V.(2020,September21).EUisselling surveillancetechtoChina, saysrightsgroup.Politico. eu. https://www.politico.eu/article/amnesty-international-eu-is-selling-spyware-to-china/

Mannocchi, F. (2019, November 3). Torture, rape and murder: Inside Tripoli's refugee detention camps. The Guardian. https://www.theguardian.com/world/2019/nov/03/ libya-migrants-tripoli-refugees-detention-camps

Meaker, M. (2020, January 10). Here's proof the UK is using drones to patrol the English Channel. Wired. https://www.wired.co.uk/article/uk-drones-migrants-english-channel 
Miller, T. (2018, November 1). Why climate action needs to target the border industrial complex. Al Jazeera. https://www.aljazeera.com/indepth/opinion/climate-action-target-borderindustrial-complex-191029104800226.html

Moerel, L., \& Storm, M. (2018, April 27). Law and autonomous systems series: Automated decisions based on profiling - information, explanation or justification? That is the question! Oxford Business Law Blog. http://www.law.ox.ac.uk/business-law-blog/blog/2018/04/ law-and-autonomous-systems-series-automated-decisions-based-profiling

Molnar, P. (2019). Technology at the margins: The Human Rights impacts of AI in migration management. Cambridge Journal of International Law, 8(2), 305-330.

Molnar, P. (2020). Technological testing grounds: Migration management experiments from the ground Up. EDRi and Refugee Law Lab, https://edri.org/wp-content/uploads/2020/11/ Technological-Testing-Grounds.pdf

Molnar, P., \& Gill, L. (2018). Bots at the gate: A Human Rights analysis of automated decisionmaking in Canada's immigration and refugee system. University of Toronto International Human Rights Program and the Citizen Lab, Munk School of Global Affairs. https://citizenlab. ca/wp-content/uploads/2018/09/IHRP-Automated-Systems-Report-Web-V2.pdf

Molnar, P., \& Naranjo, D. (2020, April 15). Surveillance won't stop the Coronavirus. The New York Times. https://www.nytimes.com/2020/04/15/opinion/coronavirus-surveillance-privacyrights.html

Molnar, P. (2021, March 31). Moria 2.0: The EU's sandbox for surveillance technologies. Euractiv. https://www.euractiv.com/section/digital/opinion/moria-2-0-the-eus-sandbox-forsurveillance-technologies/. Accessed 1 June 2021.

O'Brien, L. (2020, April 7). The far-right helped create the world's most powerful facial recognition technology. HuffPost (updated 9 April). https://www.huffpost.com/entry/clearviewai-facial-recognition-alt-right_n_5e7d028bc5b6cb08a92a5c48?guccounter=1\&guce_refer rer=aHR0cHM6Ly93d3cuZ29vZ2x1LmNvbS8\&guce_referrer_sig=AQAAACV31P-1J2Jx zXKuVg7bBIww46LyDHX9ebchaBZkIWhs3Vm0SrP0p5mK340REYTVuRuU3FXuDN 8WOOL-OizWLtoDhzowA-pbLMCHzBHwOzbKgJZGoCQozqiuEU-zluj0U6sHid4pkawJ_2Ev0MRu1aFHSME-hjuzlsdjWwTxYqm7

Okediji, R. (2018). Does intellectual property need Human Rights? NYU Journal of International Law \& Politics, 51(4), 1103-1177.

Petridi, C. (2021, April 27). Greek camps for asylum seekers to introduce partly automated surveillance systems. AlgorithmWatch. https://algorithmwatch.org/en/greek-camps-surveillance/. Accessed 1 June 2021.

Picheta, R. (2018, November 3). Passengers to face AI lie detector tests at EU airports. CNN. https:// edition.cnn.com/travel/article/ai-lie-detector-eu-airports-scli-intl/index.html. Accessed 23 July 2019.

PR Newswire. (2020, August 24). Contactless biometrics technology industry 2020-2026: Governments around the world have stepped up measures to adopt contactless biometric technologies to respond to COVID-19. Research and Markets News. https://www.prnewswire.com/news-releases/contactless-biometrics-technology-industry-2020-2026\%2D\%2Dgovernments-around-the-world-have-stepped-up-measures-to-adopt-contactless-biometrictechnologies-to-respond-to-covid-19-301117193.html

Presidential Decree 98/2019 On the organisation and operation of the unmanned aerial vehicle Force. Available (in Greek) at: https://www.kodiko.gr/nomologia/ document_navigation/570607/p.d.-98-2019

Privacy International. (n.d.). Challenging the drivers of surveillance. https://privacyinternational. org/challenging-drivers-surveillance.

Raustiala, K., \& Slaughter, A.-M. (2002). International Law, International Relations and Compliance. In W. Carlsnaes, T. Risse, \& B. A. Simmons (Eds.), Handbook of International Relations (pp. 538-539). Sage.

Roborder. (n.d.). Aims and objectives. https://roborder.eu/the-project/aims-objectives/ 
Romm, T. (2020, March 11). White House asks Silicon Valley for help to combat coronavirus, track its spread and stop misinformation. The Washington Post. https://www.washingtonpost. com/technology/2020/03/11/white-house-tech-meeting-coronavirus/

Satzewich, V. (2015). Points of entry: How Canada's immigration officers decide who gets in. UBC Press.

Scheel, S., \& Ustek-Spilda, F. (2018, June 5). Why big data cannot fix migration statistics. Refugees Deeply. https://www.newsdeeply.com/refugees/community/2018/06/05/ why-big-data-cannot-fix-migration-statistics

Solomon (@we_are_solomon). (2020). This is how the wind blows today at \#KaraTepe, the new \#refugee camp in \#Lesvos. Twitter, Sep 19, 2020, 6:34 p.m. https://twitter.com/ we_are_solomon/status/1307342343616557058?s=20

Statewatch.(2020,July 15).Viewpoint:Covid-19:From 'smart' to 'smarter' borders?Analyses.https:// www.statewatch.org/analyses/2020/viewpoint-covid-19-from-smart-to-smarter-borders/

Staton, B. (2016, May 18). Eye spy: Biometric aid system trials in Jordan. The New Humanitarian. https://www.thenewhumanitarian.org/analysis/2016/05/18/ eye-spy-biometric-aid-system-trials-jordan

The Current. (2020, March 16). COVID-19: Helping the most vulnerable Canadians; Technology deployed to fight pandemic; A warning from Italy. CBC Listen. https://www.cbc.ca/listen/ live-radio/1-63-the-current/clip/15765854-covid-19-helping-the-most-vulnerable-canadianstechnology-deployed-to-fight-pandemic-a-warning-from-italy

The World. (2019, May 23). For centuries, migrants have been said to pose public health risks. They don't. PRI. https://www.pri.org/stories/2019-05-23/ centuries-migrants-have-been-said-pose-public-health-risks-they-don-t

Trilling, D. (2020, September 22). How rescuing drowing migrants became a crime. The Guardian. https://www.theguardian.com/news/2020/sep/22/ how-rescuing-drowning-migrants-became-a-crime-iuventa-salvini-italy

Tufekci, Z. (2015). Algorithmic harms beyond Facebook and Google: Emergent challenges of computational agency. Colorado Technology Law Journal, 13, 216-217.

UNHCR. (2020, March 21). States should take action against COVID-19-related expressions of xenophobia, says UN expert. UN Human Rights News. https://www.ohchr.org/EN/NewsEvents/ Pages/DisplayNews.aspx?NewsID=25739\&LangID=E

Zureik, E., \& Hindle, K. (2004). Governance, security and technology: The case of biometrics. Studies in Political Economy, 73(1), 113-137.

Open Access This chapter is licensed under the terms of the Creative Commons Attribution 4.0 International License (http://creativecommons.org/licenses/by/4.0/), which permits use, sharing, adaptation, distribution and reproduction in any medium or format, as long as you give appropriate credit to the original author(s) and the source, provide a link to the Creative Commons license and indicate if changes were made.

The images or other third party material in this chapter are included in the chapter's Creative Commons license, unless indicated otherwise in a credit line to the material. If material is not included in the chapter's Creative Commons license and your intended use is not permitted by statutory regulation or exceeds the permitted use, you will need to obtain permission directly from the copyright holder.

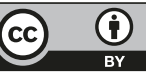

